\title{
MODERNISASI PENDIDIKAN ISLAM DALAM PERSPEKTIF NURCHOLISH MADJID
}

\author{
Oleh \\ Miftakhul Munir, M.Pd.I \\ Dosen STIT PGRI Pasuruan \\ Miftakhulm55@gmail.com
}

\begin{abstract}
Abstrak
Konsep awal Nurcholish Madjid dalam memodernisasi pendidikan berangkat dari sistem pendidikan Gontor sebagai model. Tetapi, lebih jauh lagi model pendidikan yang digagas Nurcholish Madjid adalah untuk memadukan unsur keislaman, keindonesiaan, dan keilmuan. Modernisasi pendidikan yang digagas Nurcholish Madjid pada dasarnya mengacu pada pertumbuhan metode berpikir filosofis, dan membangkitkan kembali etos keilmuan Islam yang pada masa klasik Islam telah memperhatikan hasil yang cukup gemilang. Sebagai landasan historis, modernisasi pendidikan berangkat pada penelaahan kembali kejayaan umat Islam pada masa klasik.
\end{abstract}

\section{Kata Kunci :Modernisasi Pendidikan Islam, Nurcholish Madjid}

\section{PENDAHULUAN}

Suatu tantangan terbesar bagi institusi pendidikan Islam Indonesia adalah perannya dalam pembentukan sumber daya manusia yang memiliki komposisiintelektual dan spiritual yang seimbang.Konsep pendidikan masa datang adalahketerpaduan antara khazanah keilmuan modern dan khazanah Islam yangbernuangsa budaya lokal.

Sementara itu, kondisi obyektif pendidikan Indonesia adalah sebuah potretdualisme pendidikan, yaitu pendidikan Islam tradisional dan pendidikan modern.Pendidikan Islam tradsional diwakili pesantren yang bersifat konservatif dan"hampir" steril dari ilmu-ilmu modern.Sedangkan pendidikan modern diwakilioleh lembaga pendidikan umum yang disebut sebagai "warisan kolonial" sertamadrasah-madrasah yang dalam perkembangannya telah berafiliasi dengan sistem pendidikan umum. ${ }^{1}$

Dari kedua lembaga pendidikan tersebut, pesantren adalah sistem pendidikan yang tumbuh dan lahir dari kultur Indonesia yang bersifat indigenous.Lembaga inilah yang dilirik kembali sebagai model dasar 1998), hlm. 6

'Malik Fadjar, Madrasah dan Tantangan Modernitas, (Bandung: Mizan, 202 | MODERNISASI PENDIDIKAN ISLAM DALAM PERSPEKTIF NURCHOLISH MADJID 
pengembangan konseppendidikan (baru) Indonesia.Tetapi, realitas yang terdapat dalam lembaga inimemunculkan sikap kekecewaan.

Dalam perspektif historis terlihat, ketika pemerintah colonial memperkenalkan pendidikan modern, kalangan pesantren menyikapinya denganresistansi yang kuat terhadap kebijakan pemerintah kolonial tersebut, bahkanmenempuh politik non-kooperatif dengan Belanda, serta isolatif. ${ }^{2}$ Padahalpemerintah kolonial dengan segala "iktikad baik"nya ingin menyertakan rakyat"Hindia Belanda" dalam peradaban modern tersebut. Para ulama justrumengimbanginya dengan mengembangkan dan mendirikan lebih banyakpesantren-pesantren, ${ }^{3}$ yang terasing atau mengasingkan diri dengan lingkunganwaktu itu.

Seandainya Indonesia tidak mengalami penjajahan, mungkin pertumbuhansistem pendidikan akan mengikuti jalur-jalur yang ditempuh pesantren-pesantrentersebut. Seperti pertumbuhan sistem pendidikan di negara-negara Barat, di manahampir semua universitas terkenal cikalbakalnya adalah perguruan-perguruanyang semula berorientasi keagamaan. ${ }^{4}$

Di sisi lain, sekitar tahun 1900 sampai pertengahan abad ke-20, kompromidengan sistem pendidikan modern diperlihatkan oleh madrasahmadrasah danperguruan-perguruan di Minangkabau dan Jawa. Pembaharuan dalam lembagapendidikan tersebut dibawa oleh tokoh-tokoh, seperti Haji Rasul, AbdullahAhmad, K.H. Ahmad Dahlan, dan lain-lain dengan mengadopsi corakpembaharuan pendidikan Muhammad Abduh di Mesir.

Muhammad Abduh ketika itu melihat dualisme dalam sistem pendidikandi Mesir, di satu pihak menganut sistem pendidikan Barat, di pihak lainmenggunakan pendidikan Islam tradisional. Menyikapi kondisi ini, MuhammadAbduh berusaha untuk mensintesakan dualisme pendidikan itu dengan jalanmerumuskan kembali tujuan dan sistem pendidikan. ${ }^{5}$ Pola ini

2 Azyumardi Azra membedakan respon kalangan masyarakat muslim Jawa denganmasyarakat muslim Minangkabau. Perbedaan tersebut di samping dilatarbelakangi oleh watakkultural yang relatif berbeda antara kedua masyarakat itu juga berkaitan dengan pengalamanhistoris baik dalam proses dan perkembangan Islam, maupun dalam berhadapan dengan kekuasaanBelanda. Lihat Azyumardi Azra, "Pesantren Sebuah Kontinuitas," pengantar dalam NurcholishMadjid, Bilik-bilik Pesantren, Sebuah Potret Perjalanan, (Jakarta: Paramadina, 1992), hlm. xii-xiii

${ }^{3}$ Nurcholish Madjid, Islam Doktrin dan Peradaban: Sebuah Telaah Kritis tentangMasalah Keimanan, Kemanusiaan, dan Kemodrenan, (Jakarta: Paramadina, 1992), hlm. Lxii

${ }^{4}$ Ibid.., hlm. 4

${ }^{5}$ Lihat H.A.R. Gibb dan J.H. Kramers, Shorter Encyclopedia of Islam, (Leiden: E.J. Brill, 1961), hlm. 405-407; Arbiyah Lubis, Pemikiran Muhammadiyah dan Muhammad Abduh, Suatu Studi Perbandingan, (Jakarta: Bulan Bintang, 1993), 
kemudian dicontohdan dikembangkan di Minangkabau dan Jawa.

Gerakan pembaharuan ini sangat berpengaruh dan berhasil untuk ukuranwaktu itu. Tetapi, tokoh pembaharu yang datang kemudian melihat kelemahan-kelemahan pada gerakan pembaharuan di atas, lembaga pendidikan dalam bentukini dianggap tidak relevan lagi, sebab hanya berdampak pada "pemiskinanintelektual" karena meninggalkan khazanah kitab-kitab Islam klasik.Menyikapi kondisi ini, tokoh cendikiawan muslim, Nurcholish Madjid,melontarkan ide untuk mengangkat dan mengembangkan citra pesantren dengantema modernisasi pendidikan Islam tradisional (pesantren). Oleh karena itu,penulis tertarik untuk mengadakan penelitian pemikiran Nurcholish Madjidtentang modernisasi pendidikan Islam tersebut dalam bentuk penelitian ilmiah.

\section{Biografi Nurcholish Madjid}

Nurcholish Madjid, lahir di Jombang, Jawa Timur, 17 Maret 1939. laberasal dari keluarga yang berlatar belakang budaya pesantren, karena ayahnya,H. Abdul Majid, lulusan Pesantren Tebuireng dan secara personal mempunyaihubungan dekat dengan KH. Hasyim Asy'ari, salah seorang pendiri NU. Ibunyajuga berasal dari kalangan NU, adik dari Rais Akbar NU, dari ayah seorangaktivis Serikat Dagang Islam (SDI) di Kediri, Jawa Timur. ${ }^{6}$

Sejak kecil Nurcholish Madjid mendapatkan kesempatan untuk menikmatidua cabang pendidikan, yakni pendidikan model madrasah yang lebih banyakmemberikan pelajaran agama dan pendidikan umum yang menggunakan metodepengajaran modern.Pada tingkat dasar inilah Nurcholish Madjid menjalanipendidikan di Madrasah al-Wathaniyah, yang dikelola orang tuanya sendiri, danSekolah Rakyat (SR) di Mojoanyar, Jombang.Selepas itu, Nurcholish Madjidmelanjutkan pendidikannya pada Sekolah Menengah Pertama (SMP), di Jombangpula. ${ }^{7}$

Selanjutnya Nurcholish Madjid belajar di Pesantren Darul Ulum Rejoso,Jombang. Tetapi proses pendidikannya di Rejoso ini tidak berlangsung lama,karena segera pindah ke Pesantren Darussalam Gontor, Ponorogo. Kepindahan iniberkaitan dengan pilihan politik orang tuanya, Abdul Madjid untuk tetap menjadiwarga Masyumi.Posisi politik inilah yang membuatnya kurang merasa nyamanuntuk terus belajar di Rejoso, yang merupakan salah

hlm. 56; Palrik Bannerman, Islam in Perspective: A Guide to Islamic Society, Politics and Law, (London dan New York: Bontledge, 1988), hlm. 130-136; Tim Penyusun, Ensiklopedi Islam Indonesia, (Jakarta: Djambatan, 1982), hlm. 6-7

${ }^{6}$ Siti Nadroh, Wacana Keagamaan dan Politik Nurcholish Madjid, (Jakarta: RajawaliPers, 1999), hlm. 21

${ }^{7}$ Ibid.hlm. 21 
satu pesantren NUterkemuka. ${ }^{8}$ Bukan hanya ayahnya, ibu Nurcholish Madjid pun termasuk aktivispolitik Masyumi, dan bahkan pernah menjadi juru kampanye Partai Masyumi. ${ }^{9}$

Posisi sebagai anak keluarga Masyumi inilah yang melahirkan pengaruhcukup mendalam dalam diri Nurcholish Madjid. Ayahnya telah membawa prosesperpindahan budaya politik dari pola kepemimpinan "tradisional" menujukepemimpinan Islam "modern." Masuk dan bertahannya keluarga NurcholishMadjid ke dalam Partai Masyumi bermakna bahwa keluarganya adalah lahan bagipenetrasi pengaruh pemikiran-pemikiran baru, karena saat itu, Masyumi adalahpartai Islam yang dipimpin dan dikelola oleh kaum intelektual Islam, yangmerupakan lapisan pertama santri yang berinteraksi dengan pendidikan Barat.Dengan demikian, Nurcholish Madjid berkesempatan untuk meluaskan jaringancakrawala pemikirannya, melintasi batas-batas pemikiran lokal, pada saat usianyamasih muda. ${ }^{10}$

Perpindahan pendidikan Nurcholish Madjid ke Gontor cukup berpengaruhdalam mewarnai intelektual Nurcholish Madjid. Yakni tradisi yang memadukandua kultur berbeda antara kultur liberal gaya modern Barat dengan tradisi Islamklasik. Kedua kultur ini diwujudkan dalam sistem pengajaran maupun materipelajaran. ${ }^{11}$ Literatur kitab kuning karya ulama klasik juga diajarkan di Gontortetapi dengan sistem pengajaran modern, suatu sistem yang relatif kurang dikenaldalam tradisi pesantren klasik pada umumnya.

Sebagaimana dalam pendidikan sebelumnya, prestasi Nurcholish Madjiddi Gontor cukup membanggakan, sehingga ia menjadi murid kesayangan KH.Zarkasyi, pengasuh sekaligus pimpinan pesantren.Atas prestasinya, KH. Zarkasyimenganjurkan Nurcholish Madjid, dan ia sendiri berminat, untuk melanjutkan keUniversitas Al-Azhar, Kairo. Namun karena

${ }^{8}$ Ibid., hlm. 22

${ }^{9}$ Nurcholish Madjid, “Rindu Kehidupan Zaman Masyumi,” dalam Dialog Keterbukaan:Artikulasi Nilai Islam dalam Wacana Sosial Politik Kontemporer, (Jakarta: Paramadina, 1998),hlm. 212

${ }^{10}$ Lihat Pengantar Fachri Ali, "Intelektual, Pengaruh Pemikiran dan Lingkungannya,'dalam Ibid., hlm. liii

${ }^{11}$ Mengutip penelitian Lance Castles, Barton menjelaskan tentang sistem pendidikan di Gontor.Sebagai pesantren modern, Gontor sudah dikenal lama memadukan antara tradisi klasik dan liberal sebagaimana secara sederhana direpresentasikan bahasa pengantarnya.Pada masanya sistem ini diakui sebagai progresif. Lihat Greg Barton, Gagasan Islam Liberal di Indonesia: Pemikiran Neo Modernisme, Djohan Effendi, Ahmad Wahib, dan Abdurrahman Wahid, (Jakarta: Paramadina - Pustaka Antara, 1999), hlm. 75. 
krisis yang melanda Terusan Suez,rencana itu kemudian batal. ${ }^{12}$ Selanjutnya Nurcholish Madjid hijrah ke Jakarta danmemilih studi di Fakultas Adab Jurusan Sastra Arab, IAIN Syarif Hidayatullah,fakultas yang mendalami khazanah budaya Islam, klasik maupun modern. KuliahNurcholish Madjid selesai pada tahun 1968, dengan skripsi berjudul "ArabiyyunLughatan wa 'Alamiyyun Ma'nan," yang ditulis dalam bahasa Arab. ${ }^{13}$

Dalam kaitan dengan masa muda Nurcholish Madjid, agaknya perludicatat pula bahwa saat itu situasi politik di Indonesia tengah diwarnai denganberbagai gejolak politik yang serius.Nurcholish Madjid muda tentu merasatransisi dan perubahan besar; akibat peralihan kekuasaan dari kekuatan kolonial menjadi bangsa yang merdeka.Sementara saat itu, isu utama setelah Perang Duniall dan dasawarsa 50-an adalah kemenangan sistem demokrasi.Situasi demikianjuga merupakan faktor yang harus dilihat untuk memahami keseriusan NurcholishMadjid berbicara tentang demokrasi. ${ }^{14}$

Kemudian, dorongan lain yang tidak boleh dikesampingkan dalammembuat pemikiran-pemikiran Nurcholish Madjid berwawasan luas adalahpergaulannya dengan Buya Hamka. Kurang lebih 5 tahun Nurcholish Madjidsempat menjalin hubungan yang akrab dengan Buya Hamka, pada saat itu iamasih menjadi mahasiswa dan tinggal di Masjid Agung al-Azhar, KebayoranBaru, Jakarta. Dalam kaitan ini, Komaruddin Hidayat mengungkapkan kedekatandan rasa kagumnya Nurcholish Madjid kepada Buya Hamka. Dalam berbagaiforum obrolan maupun dalam perkuliahan di Paramadina, berulangkali NurcholishMadjid mengemukakan respek dan kekagumannya pada Buya Hamka yang dinilaimampu mempertemukan pandangan kesufian, wawasan budaya dan semangat al-Qur'an sehingga dakwah dan paham keislaman yang ditawarkan Buya Hamkasangat menyentuh dan efektif untuk masyarakat Islam kota. ${ }^{15}$

${ }^{12}$ Pesantren Gontor memang memfasilitasi santri yang berprestasi ke Universitas Al-Azhar, Kairo Mesir, mengenai gagalnya rencana Nurcholish Madjid ke Al-Azhar lebih lanjut lihat, Dedy Djamaluddin dan Idi Subandy Ibrahim, Zaman Baru Islam Indonesia: Pemikiran dan Aksi Politik, (Bandung: Zaman Wacana Mulia, 1998), hlm. 124

${ }^{13}$ Siti Nadroh, op.cit., hlm. 24

${ }^{14}$ Liberasi pemahaman keIslaman salah satu kata kunci dalam trainingtraining, diskusiatau debat-debat intelektual di HMI. Hal ini salah satunya disebabkan pluralitas latar belakangtradisi keagamaan para anggotanya. Lihat Agussalim Sitompul, Sejarah Perjuangan HMI,(Surabaya: Bina Ilmu, 1976)

${ }^{15}$ Komaruddin Hidayat dalam Kata Pengantar, Nurcholish Madjid, Islam AgamaPeradaban membangun Makna Relevansi Islam dalam Sejarah, (Jakarta: Yayasan WakafParamadina, 1995), hlm. vi 
Senin, 29 Agustus 2005, bertepatan dengan 24 Rajab 1426, pukul 14.05WIB, Nurcholish Madjid kembali ke pangkuan Ilahi. Sejak Nurcholish Madjidoperasi lever di China, dirawat di rumah sakit Singapura, sampai perawatanintensif di Rumah Sakit Pondok Indah, Jakarta, teman-teman Nurcholish Madjidberdatangan memberikan doa dan dukungan moril.

Sejak dari Presiden RI, tokoh-tokoh lintas agama, aktivis LSM, jajaranintelektual, dan politikus datang silih berganti.Ini menunjukkan posisi, kiprah,dan pengaruh Nurcholish Madjid yang amat inklusif, bukan sekadar tokohpergerakan Islam, tetapi pejuang kemanusiaan dan kebangsaan.

\section{Karya-Karya Intelektual}

Sebagaimana telah disinggung di bagian depan, Nurcholish Madjidbersamasejumlah tokoh, mendirikan Yayasan Paramadina. Sejauh ini, dapatdikatakan bahwa Nurcholish Madjid adalah simbol personal dan maskot darilembaga ini.Paramadina sebagai salah satu pusat kajian keislaman, menawarkancitra baru Islam inklusif dan menghadirkan perspektif baru dalam menelaahproblem kemanusiaan kontemporer.

Secara lengkap tujuan dibentuknya Yayasan Paramadina ini menurut parapendirinya adalah: pertama, meningkatkan perkembangan dan kesadaran hidupberagama Islam yang berpandangan terbuka dan bertanggungjawab akanterjadinya masyarakat yang berserah diri kepada Allah SWT; kedua,mengembangkan pemahaman dan pemikiran agama, serta penampilan yangbersifat kesejarahan, kontekstual sehingga bermakna bagi pemecahan persoalan-persoalan baru kemanusiaan dalam suasana merdeka dan bertanggungjawab;ketiga, mengembangkan suasan kehidupan beragama yang terbuka, dinamisbernalar dan bertanggungjawab sehingga terjadi dialog yang kreatif dan kritis; dankeempat, mengembangkan sistem pendidikan agama yang berdaya hasil danberdaya guna tinggi. ${ }^{16}$

Dengan platform dan visi Paramadina semacam itu, Nurcholish Madjidmengembangkan secara konsisten jalur intelektualnya.Karya-karya intelektualnyakini identik dengan produktivitas lembaganya.Dengan model semacam iniParamadina bukan saja muncul sebagai semacam aliran tersendiri dalam mengkajiagenda keislaman dan kebangsaan, melainkan juga mempunyai wibawa keilmuantinggi. ${ }^{17}$ Sebagai lembaga pemikiran, Paramadina telah melembaga.Tetapisebagai sebuah merek atau mazhab

${ }^{16}$ Dedy Djamaluddin dan Idi Subandy Ibrahim, op.cit., hlm. 138

${ }^{17}$ Pada sebuah kesempatan, Eki Sjachruddin menyebut bahwa kelas dan wibawaintelektual Nurcholish Madjid setara dengan Soedjatmoko. Lihat Anas Urbaningrum, op.cit., hlm.67 
pemikiran, Paramadina hampir-hampirmencerminkan pribadi Nurcholish sendiri.

Sebagai intelektual, Nurcholish Madjid dapat dikatakan mempunyaiproduktivitas yang tinggi.keterlibatannya pada wilayah intelektual tampak serius,sungguh-sungguh dan sepenuhnya. la menyatakan bahwa tugas utamanya adalahmembaca, menulis dan mengajar. Bisa dimengerti jika produktivitas karya tulisdan intelektual Nurcholish Madjid sangat tinggi.dalam hal ini sedikit sajaintelektual di Indonesia yang mampu mengejar produktivitasnya. ${ }^{18}$

Berikut ini adalah beberapa karya intelektual Nurcholish Madjid yangdibukukan, yang sekaligus mencerminkan produktivitas pemikirannya itu. ${ }^{19}$ Beberapa di antaranya adalah:

1. Khazanah Intelektual Islam, tahun 1984, diterbitkan oleh Yayasan OborJakarta. Dalam buku ini, Nurcholish Madjid bertindak sebagai editor.

2. Islam, Kemoderenan dan Keindonesiaan, tahun 1987, diterbitkan olehMizan Bandung.

3. Islam, Doktrin dan Peradaban: Sebuah Telaah Kritis tentang Masalah Keimanan, Kemanusiaan dan Kemoderenan, tahun 1992, diterbitkan olehParamadina Jakarta

4. Islam Kerakyatan dan Kemoderenan: Pikiran-pikiran Nurcholish Madjid Muda, tahun 1994, diterbitkan oleh Mizan Bandung.

5. Pintu-pintu Menuju Tuhan, tahun 1994, diterbitkan oleh ParamadinaJakarta.

6. Islam Agama Peradaban: Membangun Makna dan Relevansi Doktrin Islam dalam Sejarah, tahun 1995, diterbitkan oleh Paramadina Jakarta.

7. Islam Agama Kemanusiaan: Membangun Tradisi dan Visi Baru Islam,tahun 1995, diterbitkan oleh Paramadina Jakarta.

8. Masyarakat Religius, tahun 1997, diterbitkan oleh Paramadina Jakarta.

9. Tradisi Islam: Peran dan Fungsinya dalam Pembangunan di Indonesia, tahun 1997, diterbitkan oleh Paramadina Jakarta.

10. Kaki Langit Peradaban Islam, tahun 1997, diterbitkan oleh ParamadinaJakarta.

11. Kontekstualisasi Doktrin Islam dalam Sejarah, tahun 1997, diterbitkanoleh Paramadina Jakarta.

12. Bilik-bilik Pesantren: Sebuah Potret Perjalanan, tahun 1997, diterbitkanoleh Paramadina Jakarta.

13. Dialog Keterbukaan: Artikulasi Nilai Islam dalam Wacana Sosial Politik

\footnotetext{
${ }^{18}$ Ibid.

${ }^{19}$ Siti Nadroh, op.cit., hlm. 38-44
} 
Kontemporer, tahun 1997, diterbitkan oleh Paramadina Jakarta.

14. Tigapuluh Sajian Ruhani: Renungan di Bulan Ramadhan, tahun 1998, diterbitkan oleh Mizan Bandung.

15. Cita-cita Politik Islam Era Reformasi, tahun 1999, diterbitkan olehParamadina Jakarta.16. Cendekiawan dan Religiusitas Masyarakat, tahun 1999, diterbitkan olehParamadina dan Tekad Jakarta.

Selain buku-buku itu, masih banyak karya akademis-intelektualnya yanglain yang tersebar dalam berbagai bentuk, seperti makalah, kertas kerja, artikeldan kolom. Tetapi demikian, meskipun Nurcholish Madjid diakui sebagaiintelektual yang berkelas, sampai saat ini belum ada satu bukupun yangdihasilkannya secara utuh.

Namun demikian, terlepas dari kelebihan dan kekurangannya, Nurcholish Madjid telah menjadi tokoh yang tidak sekedar berdimensi pribadi, tetapi jugatelah menjadi semacam institusi.

\section{Modernisasi Pendidikan Islam Menurut Nurcholish Madjid}

Pendidikan Islam di Indonesia masih menghadapi berbagai masalah dalamberbagai aspek.Upaya perbaikannya belum dilakukan secara mendasar, sehinggaterkesan seadanya saja. Selama ini, upaya pembaharuan pendidikan Islam secaramendasar, selalu dihambat oleh berbagai masalah mulai dari persoalan danasampai tenaga ahli. Padahal pendidikan Islam dewasa ini, dari segi apa sajaterlihat goyah terutama karena orientasi yang semakin tidak jelas. $^{20}$

Berdasarkanuraian ini, ada dua alasan pokok mengapa konsep pembaharuan pendidikan Islamdi Indonesia untuk menuju masyarakat madani sangat mendesak. (a)konsep danpraktek pendidikan Islam dirasakan terlalu sempit, artinya terlalu menekankanpada kepentingan akhirat, sedangkan ajaran Islam menekankan padakeseimbangan antara kepentingan dunia dan akhirat. Maka perlu pemikirankembali konsep pendidikan Islam yang betul-betul didasarkan pada asumsi dasartentang manusia yang akan diproses menuju masyarakat madani. (b) lembaga-lembaga pendidikan Islam yang dimiliki sekarang ini, belum atau kurang mampumemenuhi kebutuhan umat Islam dalam menghadapi tantangan dunia modern dantantangan masyarakat dan bangsa Indonesia disegala bidang. Maka, untukmenghadapi dan menuju masyarakat madani diperlukan konsep pendidikan Islamserta peran sertanya secara mendasar dalam memberdayakan umat Islam.

Suatu usaha modernisasi pendidikan hanya bisa terarah dengan

${ }^{20}$ Muslih Usa (Ed.), Pendidikan Islam di Indonesia antara Cita dan Fakta, (Yogyakarta: Tiara Wacana, 1991), hlm. 11-13 
mantapapabila didasarkan pada konsep dasar filsafat dan teori pendidikan yang mantap.Filsafat pendidikan yang mantap hanya dapat dikembangkan di atas dasar asumsi-asumsi dasar yang kokoh dan jelas tentang manusia (hakekat) kejadiannya,potensi-potensi bawaannya, tujuan hidup dan misinya di dunia ini baik sebagaiindividu maupun sebagai anggota masyarakat, hubungan dengan lingkungan danalam semesta dan akhiratnya hubungan dengan Maha Pencipta. Teori pendidikanyang mantap hanya dapat dikembangkan atas dasar pertemuan antara penerapanatau pendekatan filsafat dan pendekatan empiris. ${ }^{21}$ Sehubungan dengan itu,konsep dasar pembaharuan pendidikan Islam adalah perumusan konsep filsafatdan teoritis pendidikan yang didasarkan pada asumsi-asumsi dasar tentangmanusia dan hubungannya dengan lingkungan dan menurut ajaran Islam.

Maka, dalam usaha pembaharuan pendidikan Islam perlu dirumuskansecara jelas implikasi ayat-ayat al-Qur'an dan hadits yang menyangkut dengan"fitrah" atau potensi bawaan, misi dan tujuan hidup manusia. Karena rumusantersebut akan menjadi konsep dasar filsafat pendidikan Islam. Untuk itu, filsafatatau segala asumsi dasar pendidikan Islam hanya dapat diterapkan secara baikjikalau kondisi-kondisi lingkungan (sosial-kultural) diperhatikan.Jadi, apabilakita ingin mengadakan perubahan pendidikan Islam maka langkah awal yangharus dilakukan adalah merumuskan konsep dasar filosofis pendidikan yangsesuai dengan ajaran Islam, mengembangkan secara empris prinsip-prinsip yangmendasari keterlaksanaannya dalam konteks lingkungan (sosial-kultural) yangdalam hal ini adalah masyarakat madani.Jadi, tanpa kerangka dasar filosofis danteoritis yang kuta, maka perubahan pendidikan Islam tidak punya pondasi yangkuat dan juga tidak mempunyai arah yang pasti. ${ }^{22}$

Konsep dasar filsafat dan teoritis pendidikan Islam, harus ditempatkandalam konteks supra sistem masyarakat madani di mana pendidikan itu akanditerapkan. Apabila terlepas dari konteks "masyarakat madani", maka pendidikanmenjadi tidak relevan dengan kebutuhan umat Islam pada kondisi masyarakattersebut (masyarakat madani).Jadi, kebutuhan umat yang amat mendesaksekarang ini adalah mewujudkan dan meningkatan kualitas manusia Muslimmenuju masyarakat madani. Untuk itu umat Islam di Indonesia dipersiapkan danharus dibebaskan dari ketidaktahuannya (ignorance) akan kedudukan danperanannya dalam kehidupan "masyarakat madani" dalam konteks kehidupanberbangsa dan bernegara. Pendidikan Islam haruslah dapat meningkatkan mutuumatnya

${ }^{21}$ Anwar Jasin, op.cit., hlm. 8

${ }^{22}$ Ibid. hlm. 8-9 
dalam menuju "masyarakat madani". Kalau tidak umat Islam akanketinggalan dalam kehidupan "masyarakat madani" yaitu masyarakat ideal yangdicitacitakan bangsa ini. Maka tantangan utama yang dihadapi umat Islamsekarang adalah peningkatan mutu sumber insaninya dalam menempatkan diri danmemainkan perannya dalam komunitas masyarakat madani dengan menguasaiilmu dan teknologi yang berkembang semakin pesat.Karena, hanya mereka yangmenguasai ilmu dan teknologi modern dapat mengolah kekayaan alam yang telahdiciptakan Allah untuk manusia dan diamanatkanNya kepada manusia sebagaikhalifah dimuka bumi ini untuk diolah bagi kesejahteraan umat manusia.

Maka masyarakat madani yang diprediksi memiliki ciri; universalitas,supremasi, keabadian, pemerataan kekuatan, kebaikan dari dan untuk bersama,meraih kebajikan umum, perimbangan kebijakan umum, piranti eksternal, bukanberinteraksi pada keuntungan, dan kesempatan yang sama dan merata kepadasetiap warganya. Atas dasar konsep ini, maka konsep filsafat dan teoritispendidikan Islam dikembangkan sebagai prinsipprinsip yang mendasariketerlaksanaannya dalam kontek lingkungan masyarakat madani tersebut,sehingga pendidikan relevan dengan kondisi dan ciri sosial kultural masyarakattersebut.Maka, untuk mengantisipasi perubahan menuju "masyarakat madani",pendidikan Islam harus didisain untuk menjawab perubahan tersebut. Oleh karenaitu, usulan perubahan sebagai berikut : (a) pendidikan harus menuju padaintegritas antara ilmu agama dan ilmu umum untuk tidak melahirkan jurangpemisah antara ilmu agama dan ilmu bukan agama, karena, dalam pandanganseorang muslim, ilmu pengetahuan adalah satu yaitu yang berasal dari AllahSWT, (b) pendidikan menuju tercapainya sikap dan perilaku "toleransi", lapangdada dalam berbagai hal dan bidang, terutama toleran dalam perbedaan pendapatdan penafsiran ajaran Islam, tanpa melepaskan pendapat atau prinsipnya yangdiyakini, (c) pendidikan yang mampu menumbuhkan kemampuan untukberswadaya dan mandiri dalam kehidupan, (d) pendidikan yang menumbuhkanethos kerja, mempunyai aspirasi pada kerja, disiplin dan jujur, ${ }^{23}(\mathrm{e})$ pendidikanIslam harus didisain untuk mampu menjawab tantangan masyarakat madani.

Dalam konteks ini juga perlu pemikiran kembali tujuan dan fungsilembaga-lembaga pendidikan Islam yang ada. ${ }^{24}$ Memang diakui

${ }^{23}$ Soroyo, "Antisipasi Pendidikan Islam dan Perubahan Sosial Menjangkau Tahun 2000," dalam buku Pendidikan Islam di Indonesia antara Cita dan Fakta, Editor: Muslih Usa, (Yogyakarta: Tiara Wacana, 1991), hlm. 45-48

${ }^{24}$ Anwar Jasin, op.cit., hlm. 15 
bahwapenyesuaian lembaga-lembaga pendidikan akhir-akhir ini cukup mengemberikan,artinya lembaga-lembaga pendidikan memenuhi keinginan untuk menjadikanlembaga-lembaga tersebut sebagai tempat untuk mempelajari ilmu umum danilmu agama serta keterampilan. Tetapi pada kenyataannya penyesuaian tersebutlebih merupakan peniruan dengan tambal sulam atau dengan kata lain mengadopsimodel yang telah dilakukan oleh lembaga-lembaga pendidikan umum, artinya adaperasaan harga diri bahwa apa yang dapat dilakukan oleh lembaga-lembagapendidikan umum dapat juga dilakukan oleh lembaga-lembaga pendidikan agama,sehingga akibatnya beban kurikulum yang terlalu banyak dan cukup berat danbahkan terjadi tumpang tindih.

Lembaga-lembaga pendidikan Islam mengambil secara utuh semuakurikulum (non-agama) dari kurikulum sekolah umum, kemudian tetapmempertahankan sejumlah program pendidikan agama, sehingga banyak bahanpelajaran yang tidak dapat dicerna oleh peserta didik secara baik, sehinggaproduknya (hasilnya) serba setengah-tengah atau tanggung baik pada ilmu-ilmuumum maupun pada ilmu-ilmu agama. Untuk itu, lembaga-lembaga pendidikanIslam sebenarnya mulai memikirkan kembali disain program pendidikan untukmenuju masyarakat madani, dengan memperhatikan relevansinya dengan bentukatau kondisi serta ciri masyarakat madani. Maka untuk menuju "masyarakatmadani", lembagalembaga pendidikan Islam harus memilih satu di antara duafungsi yaitu apakah mendisain model pendidikan umum Islami yang handal danmampu bersaing secara kompotetif dengan lembaga pendidikan umum ataumengkhususkan pada disain pendidikan keagamaan yang handal dan mampubersaing secara kompotetif, misalnya mempersiapkan ulama-ulama dan mujtahid-mujtahid yang berkaliber nasional dan dunia.

\section{Konsep Pendidikan Keislaman, Keindonesiaan, dan Keilmuan}

Setelah menelaah lebih jauh kritik Nurcholish Madjid terhadap duniapendidikan Islam tradisional dan mempelajari pikiran-pikiran serta gagasan-gagasannya, nampaknya Nurcholish Madjid berobsesi menciptakan suatu sitempendidikan yang memiliki keterpaduan antara unsur keislaman, keindonesiaan, dan keilmuan. Sistem pendidikan terpadu ini diproyeksikan sebagai suatualternatif untuk menuju masyarakat madani. Untuk membuktikan tesis di atas, berikut ini akan dilihat konsep keterpaduan dalam ketiga unsur tersebut.

1. Keislaman

Islam sudah termarginalkan dalam bangunan sistem pendidikan, karenaada anggapan bahwa Islam sebagai penghambat kemajuan.Islam 
diklaim sebagaitatanan nilai yang tidak dapat hidup berdampingnan dengan sains modern.Menurut Nurcholish Madjid, Islam yang dipandang sebagai penyebab kegagalandan keterbelakangan adalah klaim-klaim warisan kolonial yang pada masa dahuludigunakan sebagai alat untuk menghadapi sikap permusuhan non-koperatif kaumulama, kyai, dan santrinya. Anggapan terhadap Islam sebagai musuh kemajuandalam pandangan Nurcholish Madjid berarti orang itu tidak memahamikeuniversalan ajaran Islam.Oleh sebab itu, penelaahan kembali terhadap ajarannilai universalitas Islam amat diperlukan, ${ }^{25}$ sehingga dapat mengatasi sikapsebagian kalangan yang meninggalkan Islam.

Ajaran Islam dengan jelas menunjukkan adanya hubungan organik antarailmu dan iman. Hubungan organik itu kemudian dibuktikan dalam sejarah Islamklasik ketika kaum muslim memiliki jiwa kosmopolit yang sejati. Atas dasarkosmopolitanisme itu umat Islam membangun peradaban dalam arti yang sebenar-benarnya yang juga berdimensi universal. ${ }^{26}$ Sebab, pada dasarnya Islam itumembawa pada kemajuan bukan sebaliknya.Sejarah telah membuktikan, Islamlahyang membawa pada zaman kekuatan dan kegemilangan.

Inilah yang memperkokoh nilai universalitas Islam yang meliputi unsursejarah, filsafat, sains, teologi dan tasawuf, serbagai tradisi keilmuan Islam klasikyang telah menaruh perhatian Nurcholish Madjid cukup tinggi.Ini terbuktidengan intensnya cabang-cabang ini dibicarakan Nurcholish Madjid bersamaKlub Kajian Agama (KKA) yang diselenggarakan oleh Yayasan WakafParamadina Jakarta.Bidang-bidang ini dilirik kembali dalam mencari bentukkonsep universitas Islam, sebagaimana yang digagas oleh Hamid Hasan Bil Ramidan Sayid Ali Asyraf. $^{27}$

Keikutsertaan dunia pendidikan Islam secara aktif dalam pembanguanIndonesia akan menampilkan Indonesia dalam bentuk "baru". Nurcholish Madjidpernah mensinyalir bahwa Indonesia yang akan

${ }^{25}$ Konsep "universalitas Islam" selalu jadi bagian penting dalam pembicaraan NurcholishMadjid, bahkan telah melandasi keseluruhan dari pola pikirnya. Selanjutnya dapat dibaca karya-karya Nurcholish Madjid, terutama, Islam Doktrin dan Peradaban, Sebuah Telaah Kritis tentangMasalah Keimanan, Kemanusiaan dan Kemodernan, cet. ke-2, (Jakarta: Paramadina, 1992).

${ }^{26}$ Nurcholish Madjid, Islam Doktrin..., hlm.24.

${ }^{27}$ Baca Hamid Hasan Bil Rami dan Sayid Ali Asyraf, Konsep Universitas Islam, terj.Machnun Husein, cet. ke-1, (Yogyakarta: Tiara Wacana Yogya, 1989), hlm. 14-21. 
datang itu seperti sosok "santriyang canggih". Nurcholish Madjid menyelaraskan Indonesia dengan santri,karena pada dasarnya sosok santri itu sebagai tampilan sikap egaliter, terbuka,kosmopolit dan demokratis.Ini merupakan pola budaya pantai, sebab sekarangpola budaya pedalaman in land culture masih mendominasi. Dengan kata lain,suatu penampilan Islam modern yang menyerap secara konstruktif dan positifkehidupan modern, namun semuanya tetap dalam nilai-nilai keislaman. ${ }^{28}$ Dalambahasa sederhana dan paling populer didengar adanya keselarasan antara iptek(ilmu pengetahuan dan teknologi) dan imtaq (iman dan taqwa). Dengan potensiinilah harapan akan terwujudnya masyarakat madani dapat dimungkinkan.

Perpaduan kedua komponen penunjang iptek dan imtaq diupayakan lewatperpaduan dua sistem pendidikan, tradisional dan modern.Memasukkan sistem pendidikan "baru" dalam dunia pendidikan Islam bukan berarti melepaskan yang"lama".Karena pada institusi pendidikan pesantren itu justru ada yang perluditumbuhkembangkan kembali.Tidak semua pada yang "lama" itu mesti dibuang.Nurcholish Madjid dalam hal ini menyerukan untuk melihat kembali kitab-kitablama "klasik" untuk menyikapi agar tidak terjadinya kemiskinan intelektual, ataudalam istilah Nurcholish Madjid kehilangan jejak riwayat intelektualisme Islam. ${ }^{29}$

Menurut Nurcholish Madjid, inilah salah satu kelemahan dan akibat daripembaharuan yang dilakukan oleh Muhammadiyah, sehingga menimbulkankesenjangan intelektual. Jejak pemahaman mereka terhadap Islam tidak lengkap.Mereka memahami Islam dari kaum orientalis, bukan dari khazanah Islam yangada.Tidak timbul lagi wacana kreatif untuk mempelajari "kitab-kitab lama"sebagai warisan intelektual Islam.Padahal khazanah keislaman terdapat dalamkitab-kitab klasik itu, jadi perlu suatu fase reorientasi tradisi.

Oleh sebab itu, menurut Nurcholish Madjid, di Indonesia seringdidengungkan tentang perlunya para sarjana keislaman mengenal apa yangdisebut "kitab kuning." Seruan itu adalah penyederhanaan dari rasa kesadaran dankeperluan kepada sikap-sikap yang lebih apresiatif terhadap warisan intelektuallslam sendiri.Apresiasi yang dikehendaki terhadap "kitab kuning" bukanlah jenisapresiasi doktrinal dan dogmatik, melainkan jenis intelektual dan akademik.Selain itu juga diharapakan

${ }^{28}$ Nurcholish Madjid, Dialog Keterbukaan..., hlm. 212.

${ }^{29}$ Nurcholish Madjid, Kaki Langit Peradaban Islam, cet. ke-1, (Jakarta: Paramadina,1997), hlm. 146 
secara wajar mengapresiasikan warisan intelektualdari luar Islam sejalan dengan petunjuk agama sendiri dalam hal sikap terhadaphikmah atau ilmu pengetahuan dari manapun datangnya. ${ }^{30}$ Sikap terhadap keduakutub warisan intelektual inipun mengindikasikan pengintegrasian keilmuandalam wacana pendidikan Islam.

Selanjutnya pada tataran yang lebih tinggi lagi bidang filsafat belummendapat tempat dalam pendidikan Islam, sehingga kedalaman ilmu seseorangdalam Islam selalu diukur sejauh mana pengetahuannya terhadap fiqh, sebagaiakibat dari fiqh oriented. Reorientasi ini telah diupayakan oleh Nurcholish Madjidmelalui Yayasan Wakaf Paramadina sebagai suatu alternatif menghadirkan Islamdi alam modern. ${ }^{31}$ Barangkali dengan upaya inilah salah satu metode untukmenghilangkan jarak dan jurang antara dunia pendidikan Islam secara khususdengan dunia pendidikan modern.

Tinggal lagi persoalan yang melilit dunia pendidikan sekarang adalahmerumuskan kajian epistemologi ilmu-ilmu umum itu yang masih terlihat kabur,kemudian merumuskan metodologi dalam mengajarkannya di dunia pendidikanlslam secara umum.Azyumardi Azra misalnya mengangkat kasus Al-Azhar.Pengalaman Al-Azhar dalam mengintegrasikan antara bidang ilmu-ilmu umumdengan ilmu-ilmu agama tersebut boleh dikatakan kurang berhasil.Adahambatanhambatan tertentu, misalnya berkaitan dengan persoalan dikotomikonseptual ketika fakultas-fakultas umum dimasukkan ke AlAzhar, tidak disertaidengan perumusan epistemologi yang jelas.Misalnya saja, bagaimana ilmu-ilmueksakta diajarkan kepada mahasiswa dalam kerangka atau visi Islam, bagaimanamemberikan warna Islam terhadap ilmu-ilmu yang bersifat umum. ${ }^{32}$ Gagasanserupa yang dilontarkan Nurcholish Madjid juga akan terbentur pada problemyang sama, karena belum konkritnya konsep epistemologi keilmuan umumtersebut dalam wacana pendidikan Islam kontemporer.

Konsep dasar yang dimunculkan Nurcholish Madjid hanya sebatasbagaimana menempatkan kembali ilmu pengetahuan dan teknologi ke dalamdaerah pengawasan nilai agama, moral dan

${ }^{30}$ Ibid., hlm. 157

${ }^{31}$ Ibid., hlm. 146

${ }^{32}$ Azyumardi Azra, "Rekonstruksi Kritis Ilmu dan Pendidikan Islam" dalam M. Anis,(pen), Rekonstruksi Pendidikan dan Tradisi Pesantren, Religiusitas Iptek, cet. ke-1, (Yogyakarta:Pustaka Pelajar, 1998), hlm. 82. 
etika. ${ }^{33}$ Karena pada prinsipnya, asalmula semua cabang ilmu pengetahuan adalah berpangkal pada ilmu agama.Ketika para intelektual muslim mampu mengembangkan dan mengislamkan ilmupengetahuan modern itu, dunia Islam akan dapat mencapai kemakmuran dalamberbagai bidang, seperti yang dicontohkan pada masa Islam klasik. Saat ini, umatlslam hanya dapat menyaksikan bekas-bekasnya saja.Buktinya sampai saat inikata Nurcholish Madjid, banyak sekali istilahistilah teknis dalam ilmupengetahuan dan teknologi modern di Barat yang berasal dari bahasa Islam,khususnya bahasa Arab.Sebagai indikator, terdapat akar-akar Islam bagi ilmupengetahuan dan teknologi modern. ${ }^{34}$ Peradaban Islam mempengaruhi Barat tidakhanya dalam bidang iptek, tetapi juga dalam bidang peradaban pada umumnya,maka dapat ditemukan pula berbagai istilah Inggris pinjaman dari bahasa Arabdan Persia. ${ }^{35}$

Dengan menyadari kondisi umat Islam, di mana tingkat

${ }^{33}$ Dalam hal ini Nurcholish Madjid tidak sependapat dengan kalangan yang bersikapaskriptif terhadap ilmu dan teknologi, antara lain Naquib Al-Attas. Bagi Nurcholish Madjid, ilmudan teknologi yang dipelajari sekarang sebagiannya memang berasal dari Barat, tetapi yangterpenting adalah bagaimana ilmu dan teknologi itu bisa ditundukkan pada suatu sistem etika yangterkuat. Dalam hal ini tentu saja sistem etika universal yang dimiliki umat Islam. Iihat NurcholishMadjid, Dilaog Keterbukaan..., hlm. 247-248.

${ }^{34}$ Istilah teknis tersebut sebagaimana dipaparkan oleh Nurcholish Madjid berikut ini,alchemy dari al-kimiya', ilmu kimia; al-cohol dari al-kuhul, alkohol; alcove dari al-qubbah, kubah;alembic dari al-anbiq, alat distilasi, algebra dari aljabr wa almusawah, aljabar dan teori equation;algorism dari al-Khawarizmi karena sarjana itu yang menemukannya; alkali dari al-qali,hidroksida, sodium, potassiun, dan lain-lain; azimuth dari al-sumut atau al-samt, puncak, penunjukarah; caliber dari qalib, cetakan atau ukuran barang-barang logam; carat dari qirath, timbanganberat tertentu; caraway dari karawya, biji tetumbuhan aromatik; cipher dari shifr, nol, nihil; elixirdari al-iksir, obat-obatan; monsoon dari mawsim, musim; nadir dari nadhir al-samt, kebalikanpuncak; saffron dari za'faran, sejenis zat pewarna, bumbu; sirocco dari sharuq, angin yang bertiupdari Timur; zenith dari samt al-ra's, arah kepala, puncak; zero dari shifr, nol, nihil. LihatNurcholish Madjid, Kaki Langit, hlm. 17.

${ }^{35}$ Istilah Inggris pinjaman dari bahasa Arab atau Persia seperti admiral dari al-amir atauamir al-bahr, pemimpin pelayaran; alfalfa dari al-fashfashah, makanan ternak utama; azure darial-lazaward, lazuardi; carafe dari gharafah, gelas minuman; coffee dari qahwah, kopi; cotton dariquthn, kapas, katun, hashish dari al-hasyisy, rerumpatan; jar dari jarrah, bejana; lute dari al-vud,tangkai kayu, menjadi senar musik; macrame dari miqramah, sejenis kain; magazine darimakhazin, tempat menyimpan barang, gudang; mohair dari mukhayyar, kain pilihan; sofa darishuffah, sofa; tariff dari ta'rifah, harga yang ditetapkan, dan lain sebagainya. Lihat NurcholishMadjid, Kaki Langit, hlm. 17-18

\section{6| MODERNISASI PENDIDIKAN ISLAM DALAM PERSPEKTIF NURCHOLISH MADJID}


pendidikanmodern rata-rata diseluruh dunia, masih lebih rendah dari bangsa-bangsa lain,maka untuk menuju ke arah masa depan yang lebih baik, Nurcholish Madjidmenyerukan kepada umat Islam dalam merespon tantangan zaman itu harusterlebih dahulu dengan menangkap pesan dalam kitab suci. Kemudian secara kritismempelajari sosok ilmu pengetahuan yang dihasilkan oleh modernitas. Upaya inimerupakan salah satu upaya untuk menemukan kembali pengetahuan baru yangmerupakan tujuan sejati intelektual Islam. ${ }^{36}$

Selanjutnya, sejalan dengan renaisans Asia yang bercirikan semangatmemunculkan kembali potensi budaya Asia yang asli, maka konsep keterpaduanpendidikan yang digagas Nurcholish Madjid berakar pula dari potensi budayalndonesia, sehingga lembaga pendidikan itu bersifat indegenous.

2. Keindonesiaan

Lebih jauh lagi, modernisasi pendidikan dimaksud diharapkan mampumenciptakan suatu lembaga pendidikan yang mempunyai identitas kultural yanglebih sejati sebagai konsep pendidikan masyarakat Indonesia baru yang didalamnya juga akan ditemukan nilai-nilai universalitas Islam yang mampumelahirkan suatu peradaban masyarakat Indonesia masa depan. Di sisi lain,lembaga ini juga mencirikan keaslian indegenous Indonesia, karena secarakultural terlahir dari budaya Indonesia yang asli. Konsep inilah agaknya yangrelevan dengan konsep pendidikan untuk menyongsong masyarakat madani.

Obsesi Nurcholish Madjid adalah mengupayakan modernisasi dengantegas dan jelas berlandasan platform kemodernan yang berakar dalamkeindonesiaan dengan dilandasi keimanan. ${ }^{37}$ Sehingga dalam satu kesempatandiskusi dan peluncuran buku Masa Lalu yang Membunuh Masa Depan: KrisisAgama Pengetahuan dan Kekuasaan dalam Kebudayaan Teknokratis karya YudiLatief di Jakarta, Nurcholish Madjid sekali lagi mengingatkan, ketika bangsagagal memahami masa lalu, maka yang akan terjadi adalah kemiskinanintelektual. ${ }^{38}$

Nurcholish Madjid lalu membandingkan dua negara (Turki dan Jepang)yang sama-sama mengejar kemodernan, namun ternyata meraih hasil yangberbeda.Turki adalah yang pertama kali melontarkan keinginan menjadi negaramodern. Turki adalah negara berpenduduk mayoritas

\footnotetext{
${ }^{36}$ Nurcholish Madjid, Islam Doktrin..., hlm. 485-486.

37 Secara mendasar dan komprehensif dapat ditemukan dalam karya NurcholishMadjid, Islam Doktrin...

38 Nurcholish Madjid, "Jangan Tinggalkan Masa lalu", dalam Republika Jum'at 25Juni 1999, hlm. 8.
} 
muslim yang dahulunyadalam sejarah pernah menjadi negara super power. Namun, ketika terjadinyarevolusi industri besar-besaran di Eropah, kemudian Turki menjadi negara yanglemah dan sering digambarkan sebagai the sick men di Eropah, berupayamengadakan modernisasi melalui tokoh-tokoh bangsanya.Pemimpin bangsa Turki Mustafa Kemal Attaturk yang bersikappositif secara berlebihan dan ekstrim menerjemahkan modern samadenganwesternisasi, sehingga diterapkanlah mulai dari hal yang sederhana (sepertimodel pakaian yang ketat harus meniru Barat, dan pelarangan pakaiantradisional Turki Usmani), sampai agenda yang serius sekali, yakni menggantihuruf Arab dengan huruf Latin. Usaha modernisasi tersebut menyebabkanTurki tercerabut dari masa lalunya.Mereka sekarang tidak bisa lagi membacawarisan intelektual masa lalunya, yang ditulis dalam bahasa Arab. $^{39}$

Lain halnya Jepang, yang relatif belakangan mengadakanpembaharuan, berhasil mencapai kemajuan-kemajuan yang amat menakjubkandan dalam beberapa hal bahkan mengungguli Barat. Tetapi, modernisasi yangdilakukan Jepang tidak sampai mengganti huruf kanji dengan huruf latin.Hasilnya bangsa tersebut tetap mempunyai kontiniutas budaya hingga 3.000 tahunsilam.Kontiniutas dan keotentikan itu pulalah yang dipertahankan dandipelihara oleh bangsa-bangsa di Barat.Sehingga uniknya kemodernan di Barattetap berakar hal yang tradisional. $^{40}$

Pengalaman Turki Usmani, kemudian Republik Turki, adalah juga tipikalpengalaman dunia Islam pada umumnya, dari segi bahwa adopsi iptek Barathanyalah atas dasar pertimbangan praktis pragmatis. Dalam wujudnya yangkongkrit dunia Islam menghendaki teknologi Barat tanpa etos ilmiyahnya, sekadarmemenuhi kebutuhan nyata yang bersifat jangka pendek. ${ }^{41}$ Untuk itu NurcholishMadjid melihat sebagai ketidakwajaran dalam upaya modernisasi, sebab melakukanmodernisasi tidak mesti menghilangkan identitas kultural yang dimiliki.

Oleh karena itu, berkaitan dengan upaya modernisasi pendidikan dilndonesia, terbuka peluang kembali untuk melirik lembaga pesantren sebagai institusipendidikan yang lahir dari budaya Indonesia yang asli.

3. Keilmuan

Persoalan mendasar yang terjadi hampir merata di dunia

\footnotetext{
${ }^{39}$ Nurcholish Madjid, Tradisi Islam..., hlm. 77-78.

${ }^{40}$ Nurcholish Madjid, "Jangan Tinggalkan...," hlm. 8.

${ }^{41}$ Nurcholish Madjid, Kaki Langit..., hlm. 23.
}

\section{8| MODERNISASI PENDIDIKAN ISLAM DALAM PERSPEKTIF NURCHOLISH MADJID}


pendidikan kaummuslim kontemporer adalah terpisahnya lembagalembaga pendidikan yangmemiliki konsentrasi dan orientasi yang berbeda. Ada lembaga yangmenitikberatkan orientasinya pada "ilmuilmu modern" dan di sisi lain ada lembagayang hanya memfokuskan diri pada "ilmu-ilmu tradisonal." Realitas kelembagaanpendidikan ini lebih dikenal dengan dualisme pendidikan.

Modernisasi pendidikan yang digagas oleh Nurcholish Madjid pada prinsipnyamenghilangkan dualisme pendidikan tersebut. Kedua bentuk lembaga itu sama-samamemiliki sisi positif yang patut dikembangkan dan juga mempunyai kelemahan yangsama sekali harus dibuang dan ditinggalkan. Usaha modernisasi NurcholishMadjid tertuju pada upaya untuk mengkompromikan kedua lembaga ini denganmemadukan sisi baik antara keduanya, sehingga pada gilirannya akan melahirkan sistem pendidikan yang ideal. Nurcholish Madjid menyebutnya dengan sistem pendidikanIndonesia menuju ke arah titik temu atau konvergensi. ${ }^{42}$ Usaha ini berawal padaperpaduan unsur-unsur keilmuan.

Upaya menghilangkan dualisme pendidikan tersebut tidak terlepas dariusaha menghilangkan dikotomi keilmuan saat sekarang.Sebab, mengakarnyapaham dikotomi keilmuan amat berpengaruh pada dinamika umat Islam itu sendiri.Pada masa kejayaan Islam, hampir tidak terlihat adanya dikotomi keilmuan antara"ilmu-ilmu umum" dan "ilmu-ilmu keislaman." ${ }^{43}$ Perkembagan ilmupengetahuan berjalan demikian pesatnya, meliputi ilmu agama, bahasa, sejarah,aljabar, fisika, kedokteran, dan lain-lain. Tokoh-tokoh seperti AlFarabi, Ibnu Sina,Ikhwan Al-Shafa, dan lain-lain menyadari bahwa kesempurnaan manusia hanya akanterwujud dengan penyerasian antara "ilmu-ilmu umum" dan "ilmu-ilmukeislaman," sebagai satu bagian yang tak terpisahkan dalam komponen keilmuandalam Islam.

42 Cikal bakal lahirnya sistem pendidikan "konvergensi" yang mempertemukan duaperangkat sistem pendidikan "madrasah" dan "sekolah" atau dengan kata lain sistem pendidikan"Islam" tradisional dan sistem pendidikan "modern" umum, telah ada sejak dicapainyakesepakatan antara Menteri Agama A. Wahid Hasyim dan Menteri Pendidikan dan Kebudayaan,Bahder Djohan (pada waktu itu dalam Kabinet Natsir dari Masyumi). Kesepakatan inimelahirkan kebijakan untuk mengadakan pelajaran umum di sekolah-sekolah agama dan matapelajaran agama pada sekolah-sekolah umum.Selanjutnya lihat Nucholish Madjid, Tradisi Islam..., hlm. 22 .

${ }^{43}$ Lihat M. Athiyah Al-Abrasyi, Dasar-Dasar Pokok Pendidikan Islam, terj. Bustami A. Ganidan Djohar Bahry, LIS., cet. Ke-7, (Jakarta: Bulan Bintang, 1993), hlm. 167-172. 
Sejarah pendidikan Islam telah menunjukkan bahwa keseimbanganantara ilmu-ilmu agama dan ilmu-ilmu dunia terdapat pada masa kejayaan dankegemilangan Islam itu.Seperti diungkapkan oleh Hasan Langgulung, pakarpendidikan, keseimbangan ini tidaklah hilang kecuali pada zaman kelemahan.Jadikelemahan dan kemunduran umat Islam bukan karena Islam, tetapi karena menjauhilslam. ${ }^{44}$ Artinya umat Islam ketika itu tidak mau lagi menerima ilmu-ilmu modernyang bersumber dari Barat.

Nurcholish Madjid sebagai seorang cendikiawan muslim yang banyakmenangkap khazanah kekayaan Islam klasik menyadari keunggulan perpaduankeilmuan yang telah mengantarkan Islam pada era keemasan dan kemajuan itu.Sementara itu realitas dunia pendidikan Islam "pesantren" tradisional di Indonesiamasih memperlihatkan keengganan untuk mengadopsi "ilmu-ilmu umum".Lembaga pendidikan ini mempertahankan aspek keilmuan Islam klasik saja.Aspek ini dari satu sisi punya nilai positif sebagai salah satu aset yang dimilikinya danpatut untuk dilirik kembali dalam membangun sistem pendidikan pada abadkeruhanian ini.Untuk kelengkapannya pesantren perlu mengadopsipengetahuan modern.

Dengan demikian, sistem pendidikan "baru" yang digagas Nurcholish Madjidini mengacu pada perpaduan kedua disiplin keilmuan tersebut. Dalam satukesempatan Nurcholish Madjid mengatakan, dunia pendidikan Islam harusmemodernisasi diri guna mengejar ketertinggalannya, dan untuk memenuhi tuntutanteknologi di masa depan. ${ }^{45}$ Pengalaman memperlihatkan bahwa untuk menguasaiteknologi, dunia pesantren masih jauh kalah bersaing di banding lembagalembagapendidikan non pesantren yang telah lebih dahulu menguasai MIPA, sebagai salahsatu prasyarat untuk menguasai teknologi. Dengan tidak mengatakan sama sekalitidak ada, karena perkembangan terakhir menunjukkan ada "pesantren khusus"yang menitikberatkan pada teknologi tertentu, seperti peternakan, pertanian,perikanan, dan lainlain. Tetapi, di samping jumlahnya yang relatif sedikit, jugapertumbuhannya relatif baru.

${ }^{44}$ Hasan Langgulung, Asas-Asas, hlm. 117

${ }^{45}$ Lihat wawancara Nurcholish Madjid dengan Republika, "Untuk Menguasai MIPA Lembaga Pendidikan Islam Mesti Memodernisasi Diri," Senin, 8 Maret 1999, hlm. 9. 


\section{DAFTAR PUSTAKA}

Malik Fadjar, 1998. Madrasah dan Tantangan Modernitas, Bandung: Mizan Nurcholish Madjid, 1992. Islam Doktrin dan Peradaban: Sebuah Telaah Kritis tentang Masalah Keimanan, Kemanusiaan, dan Kemodrenan, Jakarta: Paramadina

H.A.R. Gibb dan J.H. Kramers, Shorter 1961.Encyclopedia of Islam, Leiden: E.J. Brill

Arbiyah Lubis, 1993. Pemikiran Muhammadiyah dan Muhammad Abduh, Suatu Studi Perbandingan, Jakarta: Bulan Bintang

Palrik Bannerman, 1988. Islam in Perspective: A Guide to Islamic Society, Politics and Law, London dan New York: Bontledge

Tim Penyusun, 1982. Ensiklopedi Islam Indonesia, Jakarta: Djambatan

Siti Nadroh, 1999. Wacana Keagamaan dan Politik Nurcholish Madjid, Jakarta: Rajawali Pers

Nurcholish Madjid, 1998. "Rindu Kehidupan Zaman Masyumi," dalam Dialog Keterbukaan: Artikulasi Nilai Islam dalam Wacana Sosial Politik Kontemporer, Jakarta: Paramadina

Fachri Ali, "Intelektual, Pengaruh Pemikiran dan Lingkungannya,"

Greg Barton, 1999. Gagasan Islam Liberal di Indonesia: Pemikiran Neo Modernisme, Djohan Effendi, Ahmad Wahib, dan Abdurrahman Wahid, Jakarta: Paramadina Pustaka Antara

Dedy Djamaluddin dan Idi Subandy Ibrahim, 1998.Zaman Baru Islam Indonesia: Pemikiran dan Aksi Politik, Bandung: Zaman Wacana Mulia

Agussalim Sitompul, 1976. Sejarah Perjuangan HMI, Surabaya: Bina Ilmu

Komaruddin Hidayat 1995. dalam Kata Pengantar, Nurcholish Madjid, Islam Agama Peradaban membangun Makna Relevansi Islam dalam Sejarah, Jakarta: Yayasan Wakaf Paramadina

Muslih Usa (Ed.), 1991. Pendidikan Islam di Indonesia antara Cita dan Fakta, Yogyakarta: Tiara Wacana

Soroyo, 1991."Antisipasi Pendidikan Islam dan Perubahan Sosial Menjangkau Tahun 2000," dalam buku Pendidikan Islam di Indonesia antara Cita dan Fakta, Editor: Muslih Usa, Yogyakarta: Tiara Wacana

Hamid Hasan Bil Rami dan Sayid Ali Asyraf, 1989.Konsep Universitas Islam, terj. Machnun Husein, cet. ke-1, Yogyakarta: Tiara Wacana Yogya

Nurcholish Madjid, 1997. Kaki Langit Peradaban Islam, cet. ke-1, Jakarta: Paramadina,

Azyumardi Azra, 1998. "Rekonstruksi Kritis Ilmu dan Pendidikan Islam" dalam M. Anis, (pen), Rekonstruksi Pendidikan dan Tradisi Pesantren, Religiusitas Iptek, cet. ke-1, Yogyakarta: Pustaka Pelajar 
Nurcholish Madjid, "Jangan Tinggalkan Masa lalu", dalam Republika Jum'at 25 Juni 1999

M. Athiyah Al-Abrasyi, 1993. Dasar-Dasar Pokok Pendidikan Islam, terj. Bustami A. Gani dan Djohar Bahry, LIS., cet. Ke-7, Jakarta: Bulan Bintang, Lihat wawancara Nurcholish Madjid dengan Republika, "Untuk Menguasai MIPA Lembaga Pendidikan Islam Mesti Memodernisasi Diri," Senin, 8 Maret 1999 